\title{
Restoration in the City
}

A s I sat down to write this piece, I found it hard to believe that we are entering the second decade of the new millennium - it seems that I was writing about entering the new millennium only yesterday! Of course, in geological terms, ten years doesn't even register, unless there is a significant point event such as an impact from a meteorite. We have had a significant event, however, in terms of human demography. As we know, the global population is growing, with predictions of around nine to ten billion people alive by the middle of the century-others say that this is an underestimate. Many restoration programs are aimed at recreating assemblages of plants and animals in existence prior to 1800 , when the human population reached one billion-a long way from the time, circa 70,000 years ago, when humans nearly became extinct as a result of rapid fluctuations in climate.

But the increase in population, and the pressures that it will bring to bear on natural and agricultural systems for increased food production, perhaps at the expense of biodiversity, is not the significant event that I am mindful of. Rather it is that in this decade, the majority of the global human population no longer lives in rural areas but in cities, as estimated by the United Nations Environment Programme. Further, UNEP calculates that by 2050 around $65 \%$ of the global human population will live in urban areas. This is a result in part of people moving from rural to urban areas for a variety of reasons, including "pushes" such as agricultural mechanization reducing farm labor, but also the "pull" of cities.

As a result, the majority of the world's human population may have little direct experience of nature and the ecosystems that support us. This is a challenge and an opportunity for ecological restorationists. It is, of course, of vital importance that we continue and expand our activities to restore ecosystem function and structure in those areas outside of the areas designated as urban (nature knows no such boundaries, of course), in order to restore the natural capital upon which human society depends. But there are also fantastic opportunities to bring nature back into urban areas. Of course, many cities were founded where they are precisely because they were areas of high biodiversitytypically where very different ecosystem types merge or change abruptly-riverbanks and coastal areas are good examples. This means that old-style "concreting over" urban development has had a disproportionate impact on biodiversity-both locally and further afield.

This is why urban restoration offers such an exciting prospect. In 1996, the SER conference, held at Rutgers University and organized by Professor Steven Handel, theme was "From Paved to Protected" and had a number of examples of restoration in an urban context. There are many examples of restoration in urban areas on a site-bysite basis, and urban river corridor restorations are bringing connection between sites. The Natural Resources Group of New York City has just celebrated its 25th anniversary, having been founded by Commissioner Henry Stern in 1984, and was led in its early years by the Society's first Theodore Sperry Award winner, Marc Matsil. In that time 11,600 hectares of land have been restored-within the city limits.

We need to bring restoration back into cities, not only to restore basic ecosystem function but also to reconnect people with nature, providing inspiration to young and old alike. There is very good evidence that seeing a butterfly in an urban setting has psychological benefits - an increase in happiness. Ecological restorationists have a central role in influencing and acting in this important movementcritical for the restoration of our beautiful planet. So I applaud those restorationists, professionals and volunteers alike, who are embarking on this task with determination and gusto, from backyard plots, through green roofs and walls, to large municipal schemes. We need to make every household a place of ecological restoration-spread the word and let's get to it!
Jim Harris
Chair
Society for Ecological Restoration International 